\title{
Uporaba analitičnega hierarhičnega procesa za vrednotenje trajnostnih dejavnikov pri načrtovanju in upravljanju povodij
}

Čedalje večja rast prebivalstva in gospodarski razvoj povzročata onesnaženje vodnih virov in slabšanje njihovega ekološkega stanja. Eden izmed pristopov k reševanju tega problema zajema trajnostno upravljanje in načrtovanje povodij. V skladu z mednarodnimi sporazumi o varovanju povodij je Turčija začela temeljito spreminjati proces upravljanja in načrtovanja povodij. Trajnostno upravljanje vodnih virov, ki vključuje razne gospodarske, socialne in ekološke vidike, pa ni preprosto. $\mathrm{V}$ članku so trajnostni kazalniki razvrščeni po pomembnosti z vidika zagotavljanja dolgoročne vzdržnosti vodnih virov, za vrednotenje trajnostnih dejavnikov pri načrtovanju vodnih virov in povodij pa je uporabljena metoda analitičnega hierarhičnega procesa. Ob upoštevanju, da imajo lahko različni strokovnjaki različna mnenja, sta izbrane dejavnike ovrednotili dve skupini anketirancev (tj. univerzitetni učitelji in drugi strokovnjaki), izsledki raziskave pa so pokazali stopnjo ujemanja med njihovimi pogledi. Skupini sta podobno ovrednotili družbene, upravljavske in gospodarske dejavnike, glede dejavnikov rabe zemljišč in ekoloških dejavnikov pa so se njihova mnenja močno razlikovala. Izsledki raziskave kažejo, da bi bilo treba za oblikovanje ustreznega modela vrednotenja vodnogospodarskih načrtov povodij najprej ugotoviti in uskladiti nasprotujoča si mnenja različnih strokovnjakov.

Ključne besede: načrtovanje povodij, trajnostno upravljanje voda, analitični hierarhični proces, Turčija 


\section{Uvod}

Porečja ali povodja imajo ključno vlogo pri oskrbi z vodo, prečiščevanju vode ter obvladovanju poplav in erozije. Hitra urbanizacija, rast prebivalstva in vse večje potrebe po družbenogospodarskem razvoju čedalje bolj obremenjujejo sladkovodne vire in povzročajo propadanje mokrišč (Kennedy idr., 2012). Zaradi okoljskih problemov, povezanih s porabo in onesnaženostjo vode ter podnebnimi spremembami, je trajnostno upravljanje voda postalo eden najpomembnejših ciljev trajnostnega razvoja (Združeni narodi, 2014). Cilj vodnogospodarskih načrtov povodij je izboljšati upravljanje in izvedbo programov trajnostnega razvoja vodnih virov (Chandniha idr., 2014), oblikovani in vodeni pa so tako, da vodni viri postanejo bolj prilagodljivi, robustni in odporni proti negotovi in spreminjajoči se prihodnosti (Loucks in Beek, 2017).

Pri zgodnjih metodah trajnostnega upravljanja voda je bil poudarek na raznih indeksih in kazalnikih, ki so se nanašali na večdimenzionalne gospodarske in okoljske vidike (WCED, 1987; Basiago, 1999). Kot to navajajo Brooks idr. (2013), je upravljanje povodij proces urejanja rabe zemljišš in drugih virov $v$ povodju, katerega namen je zagotoviti želene proizvode ali storitve brez negativnega vplivanja na prst in vodne vire. Upravljanje povodij vključuje dodeljevanje vodnih virov različnim uporabnikom in za različne namene, pri čemer se je treba odločati med okoljskimi cilji in človeškimi potrebami (Barrow, 1998; Molle, 2006). Loucks in Gladwell (1999) sta predstavila kriterije, pomembne za zagotavljanje trajnosti vodnih virov, ti so vodna infrastruktura, kakovost okolja, ekonomija in finance, ustanove in družba, človeško zdravje in blagostanje ter načrtovanje in tehnologija. Cilj upravljanja povodij je obvladovati ali odpraviti probleme, kot so suše, poplave in čezmerno onesnaževanje, ki so posledica kmetijske dejavnosti in neustrezne rabe zemljǐ̌š v porečjih, ter izboljšati kakovost vode in okrepiti vodne ekosisteme (Loucks in Beek, 2017). Mays (2006) je predstavil sedem zahtev, ki morajo biti izpolnjene za zagotavljanje trajnostnega razvoja vodnih virov, te so osnovna vodna oskrba za zagotavljanje zdravja ljudi, osnovna vodna oskrba za zagotavljanje zdravja ekosistemov, ustrezna kakovost vode, dolgoročna obnovljivost vodnih virov, razpoložljivost informacij o vodnih virih za vse sektorje, institucionalni načrti za reševanje sporov glede vode in participativno odločanje o zadevah, povezanih z vodno oskrbo. Trajnostno načrtovanje in upravljanje povodij pa je kompleksen proces, prepleten z družbenogospodarskimi, ekološkimi, okoljsko-upravljavskimi in tehnološkimi dejavniki (Lal idr., 2001; Crase in Cooper, 2015; Srinivas idr., 2018).

Od konca 19. stoletja se za zagotavljanje trajnostnega razvoja vodnih virov uporablja pristop celovitega upravljanja vodnih virov, ki združuje gospodarske, družbene in okoljske vidike (Internet 1; Kharrazi, 2016). Spodbuja usklajen razvoj in upravljanje voda, zemljišč in drugih virov ter s tem zagotavlja čim bolj enakomerno porazdelitev posledične ekonomske in socialne blaginje brez ogrožanja trajnosti ključnih ekosistemov (Global Water Partnership, 2000). Omenjeni pristop je večdimenzionalen, saj vključuje t. i. trajnostni trikotnik (gospodarstvo, okolje in družba), zakonodajo in zdravstvena vprašanja, tehnologijo, institucionalne in politične zadeve ter zgodovinska in kulturna vprašanja (Thomas in Durham, 2003).

Drug pristop, ki spodbuja trajnostni razvoj vodnih sistemov, je ocena ranljivosti vodnih virov. $\mathrm{Na}$ ranljivost vodnih virov vplivajo naravni (fizični in ekološki), gospodarski in družbeni dejavniki ter pristojne ustanove in upravljanje, iz rezultata njenega proučevanja pa je razvidno, koliko lahko človeška dejavnost in naravni dogodki škodujejo vodnemu sistemu. Poleg tega na podlagi rezultata proučevanja ranljivosti določimo stopnjo občutjivosti vodnega vira na podnebne spremembe, poplave, suše, pomanjkanje vode, onesnaženost vode ipd. Bolj ko navedeni pojavi poškodujejo vodne vire, težje je te vodne vire dolgoročno vzdrževati. Dejavnike ranljivosti vodnega vira lahko razdelimo v štiri skupine: fizične, gospodarske, družbene in okoljske (Füssel, 2007, navedeno v Ide idr., 2019). Ta rezultat proučevanja ranljivosti omogoča boljše razumevanje značilnosti vodnih virov in zagotavlja znanstveno podlago za odločitve pri načrtovanju in upravljanju vodnih virov (Ide idr., 2019). Ta ranljivost se lahko proučuje z dvema kvantitativnima metodama: $s$ funkcijsko metodo, ki se osredotoča na značilnosti fizičnega mehanizma ranljivosti vodnih virov, in z indeksno metodo, ki se osredotoča na količino vodnih virov in kakovost vode (Chen idr., 2018). Indeksna metoda vključuje te štiri glavne korake: izbor, določanje uteži, normalizacijo in agregacijo dejavnikov (Ide idr., 2019).

$\mathrm{Z}$ vidika načel trajnostnega razvoja oba navedena pristopa $\mathrm{k}$ načrtovanju in upravljanju povodij vključujeta pet področij načrtovanja: ekološko načrtovanje, katerega cilj je ohraniti mokrišča, načrtovanje rabe zemljišč in infrastrukture, katerega namen je vzpostaviti ustrezno vrsto rabe zemljǐ̌š v povodju (Kirby in White, 1994), družbeno načrtovanje, katerega namen je spodbuditi družbene spremembe in izboljšati življenjske razmere (Keating, 1993; Basiago, 1999), gospodarsko načrtovanje za povečanje gospodarskih koristi, ki jih zagotavlja celotno povodje (Cox, 1987), in upravljavsko ali upravno načrtovanje, katerega cilj je določiti institucionalno zgradbo in metode sodelovanja za uresničevanje zahtev načrta (Kirby in White, 1994; Mencio idr., 2010).

V Turčiji se vodne potrebe prebivalcev, kmetijstva, industrije in energetike od druge polovice 20. stoletja večajo, kar čedalje bolj obremenjuje vodne vire. Do osemdesetih let 20. stoletja se je 
pri upravljanju voda upoštevala samo količina vode, načrti so se izdelovali samo za posamezne vrste rabe in težave so se reševale posamično. Nato so odgovorni organi sprejeli številne zakone in predpise za varovanje vodnih virov, na področju njihovega upravljanja pa se je uveljavil celovit pogled na kakovost vode. Poleg tega je Turčija podpisala več mednarodnih sporazumov in deklaracij, povezanih $\mathrm{z}$ vodnimi vprašanji ter načrtovanjem in varovanjem povodij v državi. Od leta 2005 država sodeluje v pristopnih pogajanjih z EU in si prizadeva izpolnjevati zahteve iz okvirne direktive o vodah - tj. najpomembnejše okoljske direktive, ki jo je Evropska komisija sprejela leta 2000. Omenjena direktiva poudarja pomen tako količine kot kakovosti vode, vzpostavlja celovit upravljavski pristop, ki temelji na povodjih, in določa okvir za varovanje vseh voda (obalnega morja, površinskih voda, somornic in podzemne vode) razen morij (Bilen, 2008). V skladu z evropsko direktivo o vodah in celovitim upravljanjem vodnih virov je Turčija tako uvedla številne spremembe pri upravljanju in načrtovanju povodij.

Zdi se, da Turčija nujno potrebuje model vrednotenja dejavnikov, ki imajo pomembno vlogo pri načrtovanju povodij ter omogočajo celovit in trajnosten načrtovalski in upravljavski pristop. V Turčiji je 25 povodij z različnimi geografskimi, fizikalnimi in hidrološkimi značilnostmi. Ministrstvo za gozdarstvo in vode, ki je odgovorno za upravljanje povodij, je leta 2013 začelo pripravljati upravljavske načrte za varovanje vodnih teles, ti načrti temeljiijo na povodjih ter se osredotočajo na varovanje in ohranjanje površinskih voda in podtalnice, na njihove kemijsko-fizikalne značilnosti in ekološko stanje ter na količino vode. Turčija je poleg tega začela pripravljati vodnogospodarske načrte za vire pitne vode, pri čemer razvija predpise in politiko varovanja virov pitne vode. Čeprav je pri upravljanju povodij dosegla že pomembne rezultate, kot je povečano število čistilnih naprav (Türkiye Cumhuriyeti Kalkınma Bakanlğğ, 2014), upravno sodelovanje in primerne raziskave kakovosti, ekosistemskih storitev in krajinskih značilnosti povodij (Tezer idr., 2018), mora na nekaterih drugih področjih, kot so javna participacija, decentralizacija uprave, vodna politika, predpisi in tehnologija, potrebna za ekološko recikliranje ter merjenje in nadzor kakovosti vode, poskrbeti za izboljšave. Cilj članka je zato ovrednotiti glavne trajnostne dejavnike pri načrtovanju upravljanja povodij ter analizirati in primerjati mnenja univerzitetnih učiteljev in drugih strokovnjakov, zaposlenih $\mathrm{v}$ vodnogospodarskih ustanovah, o pomembnosti posameznih načrtovalskih dejavnikov pri upravljanju povodij. Na podlagi rezultatov bo lažje razumeti različne poglede teh dveh skupin anketirancev na trajnostne dejavnike in proučiti morebiten vpliv razlik v njihovih vrednotenjih načrtovalskih kriterijev na trajnostni razvoj povodij.

\section{Metode}

\subsection{Raziskovalni cilji}

Glavni cilj raziskave je bil oblikovati model vrednotenja trajnostnih kazalnikov pri načrtovanju in upravljanju vodnih virov. Njeni avtorji so poskušali na podlagi strokovnih mnenj določiti povezave med spremenljivkami trajnosti povodij. Predvidevali so, da se lahko odločitve in mnenja univerzitetnih učiteljev (nosilcev znanja) in drugih strokovnjakov (ki imajo praktične izkušnje s področja načrtovanja in upravljanja vodnih virov) razlikujejo. Preden se oblikuje model vrednotenja kriterijev trajnosti povodij, je bilo zato treba razumeti nasprotujoča si mnenja strokovnjakov. V članku so najprej na podlagi pregleda literature določeni glavni kriteriji in kazalniki, nato pa je oblikovana hierarhija kazalnikov z vidika trajnostnega upravljanja in načrtovanja povodij. Sledi kvantitativno vrednotenje izbranih dejavnikov z uporabo kvantitativne metode odločanja, tj. analitičnega hierarhičnega procesa, pri katerem so univerzitetni učitelji in drugi strokovnjaki z znanjem in izkušnjami s področja upravljanja povodij določili uteži dejavnikom in poddejavnikom načrtovanja povodij. Raziskava, predstavljena v tem članku, je temeljila na treh glavnih korakih: na oblikovanju hierarhije, določanju uteži trajnostnim kazalnikom in oblikovanju vprašalnika.

\subsection{Oblikovanje hierarhije}

Za najpomembnejšo enoto upravljanja vodnih območij so bila določena povodja, ki vključujejo vodo v rekah, vodonosnikih in (umetnih) jezerih ter obsegajo najrazličnejšo rabo zemljišč, od gozdov in kmetijskih površin do predmestij in mest. Povodje ni samo hidrološka enota, ampak tudi družbenopolitična entiteta, ki ima pomembno vlogo pri zagotavljanju hrane in gospodarske varnosti ljudem, ki živijo na zadevnem območju (Wani idr., 2008). Voda v povodjih je ključna za oskrbo gospodinjstev, industrije in kmetijstva (New York State Department of State, 2009), upravljanje in načrtovanje povodij pa vpliva na ljudi in domače živali, ki na njih živijo. Da bi oblikovali jasen okvir trajnostnega razvoja povodij, so avtorji $\mathrm{v}$ raziskavi določili glavna področja, dejavnike in poddejavnike trajnostnega upravljanja in načrtovanja povodij (glej Sliko 1).

Določenih je bilo teh pet glavnih vidikov ali področij trajnostnega načrtovanja in upravljanja povodij:

- ekologija: trenutno uporabo posameznega vodnega vira bi bilo treba upravljati tako, da se ohranjajo najpomembnejši ekološki sistemi in se zagotovi, da bodo lahko isti vir uporabljale tudi prihodnje generacije (Jønch-Clausen in Fugl, 2001). Glavni kazalniki okoljske trajnosti, določeni v tej raziskavi, so vodni viri (Ouyang, 2012), drugi 


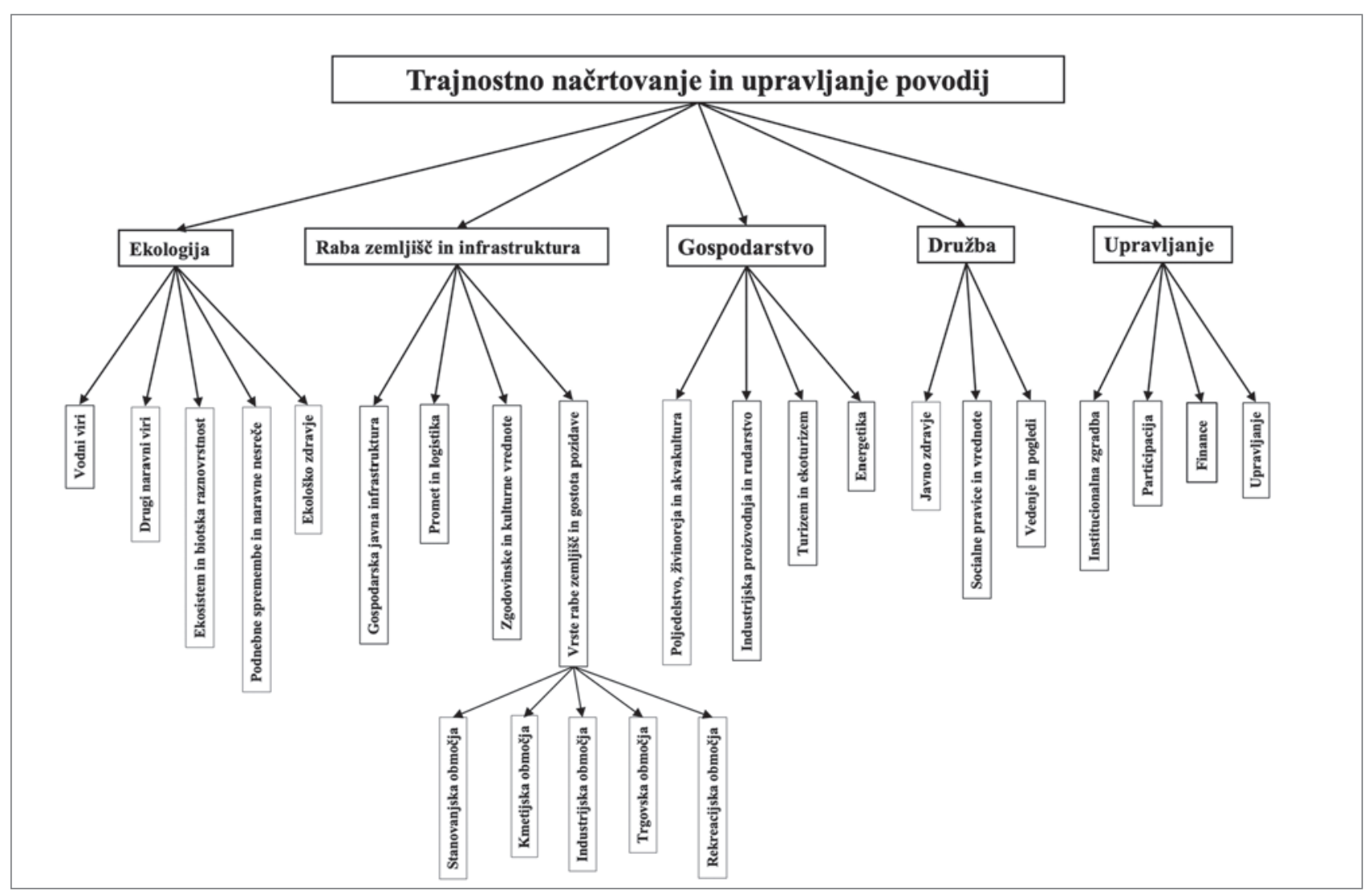

Slika 1: Pet glavnih področij trajnostnega upravljanja in načrtovanja vodnih virov z dvajsetimi dejavniki in petimi poddejavniki (ilustracija: avtorji)

naravni viri (zrak, prst in gozdovi), okoljski problemi npr. podnebne spremembe (Räsänen idr., 2017) in naravne nesreče -, ekosistem in biotska raznovrstnost (Arthington idr., 2009) ter ekološko zdravje;

- raba zemljišč in infrastruktura: to področje se nanaša na zahteve po uporabi ustreznih fizikalnih ved in tehnologije pri načrtovanju povodij, na podlagi česar se uskladijo nasprotujoči si interesi različnih vrst rabe zemljišč. Zagotavljati trajnost grajenega okolja pomeni ohranjati človeške vire in tehnologijo v daljšem obdobju (Yang idr., 2016). V to kategorijo spadajo zanesljivost, zmogljivost in stopnja obnove infrastrukture, promet in logistika, zgodovinske in kulturne vrednote ter raba zemljišč in gostota pozidave;

- družba: zaradi rasti prebivalstva in družbenogospodarskega razvoja potrebe po vodi nenehno naraščajo, $s$ tem pa se veča tudi obremenjenost vodnih virov in nevarnost pomanjkanja vode (Zhou idr., 2018). V načrtovalskem procesu je treba v ospredje postaviti temeljno človekovo pravico dostopa do vode ustrezne količine in kakovosti, da se ohranjanja dobro počutje ljudi (Shen idr., 2011). To področje se nanaša na predpise, ki podpirajo družbene spremembe in boljše življenjske razmere, pri čemer morajo upoštevati, kaj ljudje od povodja potrebujejo.
V tem članku so kot glavni družbeni dejavniki trajnostnega upravljanja in načrtovanja povodij določeni socialne pravice in vrednote, javno zdravje in vedenje prebivalcev (preference in mnenja);

- gospodarstvo: namen tega načrtovalskega področja je čim bolj povečati gospodarske koristi, ki jih zagotavlja celotno povodje, in zagotoviti, da so pri njegovem načrtovanju in upravljanju stroški in koristi enakomerno porazdeljeni (Cox, 1987). Razvoj poljedelstva, živinoreje in akvakulture (kot primarnih gospodarskih virov), energetika, turizem, razvoj industrije in rudarstva ter trgovske dejavnosti so bili prepoznani kot pomembni dejavniki izboljšanja gospodarstva celotnega povodja (Jønch-Clausen in Fugl, 2001; Shen idr., 2011);

- upravljanje: cilj tega področja je zagotoviti neprekinjen dolgoročni nadzor nad načrtovanjem povodij. Zahteva vključenost najrazličnejših inženirjev pod neposrednim nadzorom vodstvenega osebja (Kirby in White, 1994) ter zajema predpise, ki se nanašajo na institucionalno zgradbo (institucionalno povezanost in zmogljivost; $\mathrm{Di}$ nar idr., 2007; Belay idr., 2010), participacijo javnosti in deležnikov, upravljavske tehnike in orodja ter finance in javna sredstva na področju načrtovanja in upravljanja vodnih virov. 


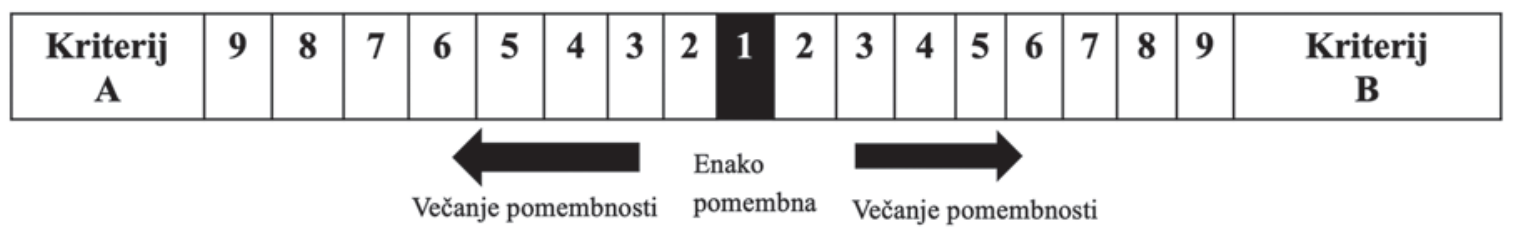

Slika 2: Lestvica pomembnosti pri parni primerjavi kriterijev (A in B) (vir: Saaty, 1994)

\subsection{Določanje uteži trajnostnim kazalnikom}

Avtorji so za proučevanje povezav med trajnostnimi dejavniki uporabili metodo analitičnega hierarhičnega procesa ( $\mathrm{v}$ nadaljevanju: AHP), pri čemer so vsakemu kriteriju trajnostnega upravljanja in načrtovanja povodij dodelili numerično vrednost. AHP, ki ga je v sedemdesetih letih 20. stoletja razvil Thomas L. Saaty, je metoda večkriterijskega odločanja, ki omogoča boljše vrednotenje subjektivnih kriterijev načrtov povodij. Uporablja se na najrazličnejših področjih, na primer za določanje uteži glavnim gonilom urbane rasti (Thapa in Murayama, 2010), razvrščanje dejavnosti, ki podpirajo razvoj podeželja, po pomembnosti (Oddershede idr., 2007), določanje glavnih kazalnikov trajnostnega razvoja mest (Michael idr., 2013) in vrednotenje fizičnih značilnosti pločnikov, ki lahko vplivajo na zadovoljstvo pešcev (Shafabakhsh idr., 2015). Poleg tega je bila navedena metoda v procesu upravljanja povodij uporabljena za izbiro primernega načina čiščenja odplak (Curiel-Esparza idr., 2014), upravnika javnega vodovodnega sistema (Ruiz-Villaverde idr., 2013) in primernih načinov upravljanja vodnih virov (Thungngern idr., 2017) ter analizo mnenj prebivalcev o uspešnem upravljanju voda (Yavuz in Baycan, 2013). S to metodo so avtorji tega članka po pomembnosti razvrstili vse dejavnike načrtovanja vodnih virov $z$ vidika načel trajnostnega razvoja, izdelali parne primerjave vseh kriterijev in jih pretvorili v numerične vrednosti. Uporaba metode AHP v predstavljeni raziskavi je omejena na določanje uteži in vrednotenje načrtovalskih kriterijev, na podlagi česar so razvrščeni glede na pomembnost pri načrtovanju in upravljanju povodij.

\subsection{Oblikovanje vprašalnika}

Za izdelavo parnih primerjav je bil v aplikaciji Google Forms pripravljen spletni vprašalnik, ta je bil nato poslan univerzitetnim učiteljem in drugim strokovnjakom, ki so ovrednotili posamezne načrtovalske kriterije. Vzorec anketirancev je bil tako omejen na posameznike, ki imajo ustrezno znanje ali izkušnje s področja vodnogospodarskega upravljanja in načrtovanja. Na podlagi vprašalnika so bila pridobljena strokovna mnenja o pomembnosti načrtovalskih dejavnikov pri trajno-
Preglednica 1: Lestvica pomembnosti po metodi AHP

\begin{tabular}{ll}
\hline Vrednost & Pomembnost \\
\hline 1 & Enaka \\
\hline 2 & Enaka do zmerna \\
\hline 3 & Zmerna \\
\hline 4 & Zmerna do močna \\
\hline 5 & Močna \\
\hline 7 & Močna do zelo močna \\
\hline 8 & Zelo močna \\
\hline 9 & Zelo močna do izjemna \\
\hline
\end{tabular}

Vir: Saaty (1994)

stnem upravljanju in načrtovanju povodij. Strokovnjaki so $s$ parnimi primerjavami določali, kako pomemben je prvi kriterij iz para glede na drugega, pri čemer so izbirali med naslednjimi možnostmi: enaka pomembnost, zmerna pomembnost, močna pomembnost, zelo močna pomembnost in izjemna pomembnost (Preglednica 1). Za določanje vrednosti primerjav je bila uporabljena lestvica od 1 do 9 , pri čemer 1 pomeni, da sta kriterija enako pomembna, 9 pa, da je v matriki parnih primerjav en kriterij veliko pomembnejši od drugega (Slika 2).

Spletni vprašalnik je bil poslan 20 univerzitetnim učiteljem in 17 drugim strokovnjakom, zaposlenim na generalnem direktoratu za hidrotehnične objekte (DSI; 4 osebe), v istanbulskem javnem komunalnem podjetju (ISKI; 6 oseb) ali na turškem ministrstvu za gozdarstvo in vode (7 oseb). Univerzitetni učitelji so zastopali različna področja, kot so urbanistično in regionalno načrtovanje (6 oseb), krajinska arhitektura (7 oseb), gozdarstvo (6 oseb) in okoljsko inženirstvo (1 oseba). Drugi strokovnjaki pa so imeli diplomo (65\%) ali magisterij (35\%) iz enega od naslednjih področij: okoljsko inženirstvo (50\%), urbanizem (40\%) in gradbeništvo (10\%).

Parne primerjave spremenljivk na treh ravneh so urejene $\mathrm{v}$ kvadratno matriko. Diagonalni elementi matrike so enaki 1 , kriterij v vrstici $i$ pa je bolǰ̌i kot kriterij v stolpcu $j$, če je vrednost obeh večja od 1 . Drugače velja ravno nasprotno (Bhushan 
Preglednica 2: Primer kvadratne matrike parnih primerjav treh podkriterijev

\begin{tabular}{llllll} 
& Podkriterij 1 & Podkriterij 2 & Podkriterij 3 & $\begin{array}{l}\text { n-ti koren zmnožka } \\
\text { vrednosti }\end{array}$ & $\begin{array}{l}\text { Normalizirani lastni } \\
\text { vektor }\end{array}$ \\
\hline Podkriterij 1 & 1 & 2 & 8 & 2,51 & 0,594 \\
\hline Podkriterij 2 & $1 / 2$ & 1 & 6 & 1,44 & 0,341 \\
\hline Podkriterij 3 & $1 / 8$ & $1 / 6$ & 1 & 0,275 & 0,065 \\
\hline
\end{tabular}

Vir: Bhushan in Rai (2004)

in Rai, 2004; Preglednica 2). Z izračunom največje lastne vrednosti primerjalne matrike in njeno normalizacijo so avtorji določili relativno pomembnost različnih kriterijev. Lastni vektor so izračunali tako, da so zmnožili vse podatke v vsaki vrstici in nato izračunali $n$-ti koren tega zmnožka (enačba 1). Nato so $n$-te korene sešteli, končno vsoto pa uporabili za normalizacijo elementov lastnega vektorja, tako da je njihova vsota enaka 1,00 (Coyle, 2004). Elementom normaliziranega lastnega vektorja pravimo uteži (posameznega kriterija ali podkriterija).

Enačba 1: $\mathrm{n}$-ti koren zmnožka podatkov $=\Pi=\sqrt{ }(\mathrm{n} \& \mathrm{a} 1 \mathrm{a} 2 \mathrm{a} 3 \mathrm{a} 4 \ldots \ldots)$ (vir: Coyle, 2004)

V raziskavi je bilo uporabljeno programsko orodje Super Decision, ki omogoča primerno izvedbo metode AHP (tj. izračun podatkov in oblikovanje matrik). Program je leta 1996 s svojo ekipo razvil Thomas L. Saaty, da bi posameznikom pomagal sklepati racionalnejše odločitve. Avtorji so v program vnesli mnenja anketirancev, na podlagi česar so pridobili rezultate in določili stopnjo njihove občutljivosti, kar je potrdilo ali ovrglo veljavnost podanih odgovorov. Pri tem so v program vnesli povprečne vrednosti odgovorov iz vprašalnika, $s$ čimer so določili končne uteži in normalizirane vrednosti. Tako so pridobili primerjalne matrike in diagrame $s$ sprejemljivo stopnjo konsistentnosti (ki po Sattyju ne sme biti večja od 0,1).

\section{Rezultati}

Povprečne vrednosti odgovorov dveh skupin anketirancev (univerzitetnih učiteljev in drugih strokovnjakov) so bile primerjane in razvrščene po pomembnosti. Normalizirane uteži so povzete v Preglednici 3, ki vsebuje kvantitativne vrednosti za vsak kriterij glede na skupino anketirancev. Avtorji so predvidevali, da bodo pri primerjavah mnenj obeh skupin o glavnih načrtovalskih dejavnikih, ki spodbujajo trajnostno upravljanje povodij, rezultati pokazali jasne razlike in podobnosti. Pri razvrščanju štirih glavnih področij, ki jih je treba upoštevati pri trajnostnem upravljanju in načrtovanju povodij, sta obe skupini na prvo mesto po pomembnosti postavili ekologijo in upravljanje voda. Univerzitetni učitelji so za najpomemb- nejši dejavnik izbrali ekologijo (42\%), drugi strokovnjaki pa upravljanje voda (36\%). Univerzitetni učitelji so najmanjši pomen pripisali gospodarstvu ( $8 \%)$, drugi strokovnjaki pa rabi zemljišč in infrastrukturi ( $5 \%$ ). To bi lahko bil tudi razlog za neusklajenost urbanizma in upravljanja povodij. Anketiranci so za tretji najpomembnejši dejavnik trajnosti povodij izbrali družbo.

Pri določanju uteži ekološkim dejavnikom je med obema skupinama opazno precejšnje neskladje. Univerzitetni učitelji so največji pomen pripisali ekosistemskim funkcijam in biotski raznovrstnosti (28\%), vodne vire pa so po pomembnosti izenačili z drugimi naravnimi viri. Po mnenju drugih strokovnjakov pa so na področju ekologije najpomembnejši naravni viri $(35 \%)$ in ekološko zdravje (26\%). Zdi se, da so vrednotenja drugih strokovnjakov bolj logična glede na trenutne težave, povezane s kakovostjo vode in onesnaženostjo naravnega okolja v državi, hkrati pa kažejo, da so drugi strokovnjaki slabše seznanjeni s pomenom ekoloških funkcij in ekosistemskih ciklov v vodnem sistemu. Analize ekosistemskih storitev in funkcij v povodjih spadajo med najpomembnejše analize pri načrtovanju in upravljanju vodnih območij.

Pri rabi zemljišč in infrastrukturi so univerzitetni učitelji največji pomen pripisali raznim vrstam rabe zemljišč in gostoti njihove pozidave (51\%), drugi strokovnjaki pa so kot najpomembnejše ovrednotili zgodovinske in kulturne vrednote ter gospodarsko javno infrastrukturo (39\%). Po mnenju obeh skupin je promet najmanj pomemben. Glavna razlika med odgovori obeh skupin je bila pri dejavniku vrste rabe zemljišč in gostota pozidave, ki ga je kot pomembnega ovrednotilo samo $14 \%$ drugih strokovnjakov. $Z$ vidika vplivov rabe zemljišč na kakovost vode in okolje povodij sta pomemben del načrtovanja in upravljanja povodij tudi vrednotenje rabe zemljišč in ustrezno coniranje. Če odločevalci med načrtovalskimi dejavniki ne upoštevajo rabe zemljišč, lahko v povodjih ali porečjih nastanejo resne težave.

Pri določanju uteži gospodarskim dejavnikom sta imeli obe skupini podobna mnenja. Na prvo mesto sta postavili poljedelstvo, živinorejo in akvakulturo, sledili so 
Preglednica 3: Normalizirane uteži in vrednosti glede na skupino anketirancev (univerzitetne učitelje in druge strokovnjake), pridobljene z metodo AHP

\begin{tabular}{|c|c|c|c|c|c|}
\hline \multirow{2}{*}{$\begin{array}{l}\text { Trajnostno } \\
\text { področje }\end{array}$} & \multicolumn{2}{|l|}{ Uteži } & \multirow[t]{2}{*}{ Dejavniki } & \multicolumn{2}{|l|}{ Uteži } \\
\hline & Univ. učitelji & $\begin{array}{l}\text { Drugi } \\
\text { strokovnjaki }\end{array}$ & & Univ. učitelji & Drugi strokovnjaki \\
\hline \multirow{5}{*}{ Ekologija } & 0,418 & 0,347 & Vodni viri & 0,220 & 0,349 \\
\hline & & & Drugi naravni viri & 0,215 & 0,142 \\
\hline & & & Ekosistem in biotska raznovrstnost & 0,275 & 0,086 \\
\hline & & & Podnebne spremembe in naravne nesreče & 0,200 & 0,167 \\
\hline & & & Ekološko zdravje & 0,090 & 0,256 \\
\hline \multirow{4}{*}{$\begin{array}{l}\text { Raba zemljišč in } \\
\text { infrastruktura }\end{array}$} & 0,102 & 0,052 & Gospodarska javna infrastruktura & 0,223 & 0,385 \\
\hline & & & Promet in logistika & 0,114 & 0,087 \\
\hline & & & Vrste rabe zemljišč in gostota pozidave & 0,514 & 0,143 \\
\hline & & & Zgodovinske in kulturne vrednote & 0,149 & 0,385 \\
\hline \multirow{4}{*}{ Gospodarstvo } & 0,084 & 0,107 & Poljedelstvo, živinoreja, akvakultura & 0,578 & 0,528 \\
\hline & & & Industrijska proizvodnja in rudarstvo & 0,112 & 0,081 \\
\hline & & & Turizem in ekoturizem & 0,213 & 0,300 \\
\hline & & & Energetika & 0,097 & 0,091 \\
\hline \multirow{3}{*}{ Družba } & 0,124 & 0,138 & Socialne pravice in vrednote & 0,311 & 0,249 \\
\hline & & & Javno zdravje & 0,493 & 0,594 \\
\hline & & & Vedenje in pogledi & 0,196 & 0,157 \\
\hline \multirow{4}{*}{ Upravljanje } & 0,273 & 0,356 & Institucionalna zgradba & 0,205 & 0,213 \\
\hline & & & Participacija & 0,288 & 0,376 \\
\hline & & & Finance & 0,169 & 0,137 \\
\hline & & & Upravljanje & 0,338 & 0,274 \\
\hline Skupaj & 1 & 1 & & 1 & 1 \\
\hline
\end{tabular}
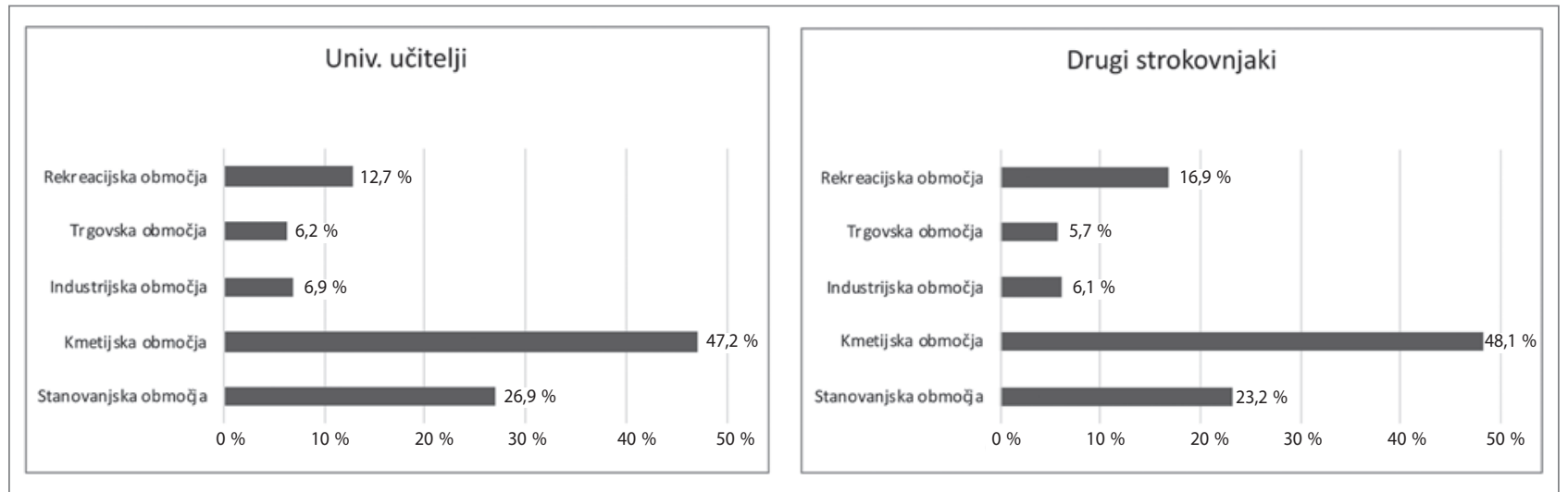

Slika 3: Primerjava odgovorov obeh skupin pri vrednotenju poddejavnikov rabe zemljišč pri načrtovanju povodij (ilustracija: avtorji)

turizem, industrijska proizvodnja in rudarstvo ter energetika. Drugi strokovnjaki so turizmu pripisali nekoliko večjo pomembnost (30 \%) kot univerzitetni učitelji (21\%), za kar je razlog morda to, da imajo drugi strokovnjaki več izkušenj in informacij glede pozitivnih vplivov turizma na gospodarstvo $\mathrm{v}$ turških povodjih. Pri razvrščanju dejavnikov, povezanih z družbo, sta skupini kot najpomembnejše ovrednotili javno zdravje $(50-60 \%)$, nato socialne pravice in vrednote $(25-31 \%)$ ter nazadnje vedenje in poglede (16-20\%). Vrednotenja se zdijo zanesljiva, saj ima vsakdo pravico do dostopa do varne in čiste vode ter urejene kanalizacije. Čeprav je bil dejavnik javno vedenje ovrednoten kot najmanj pomemben, to še ne pomeni, da ga lahko pri projektih načrtovanja povodij preprosto prezremo. Tudi pri vrednotenju upravljavskih dejavnikov sta imeli skupini podobna mnenja. Za najpomembnejša dejavnika sta določili upravljanje in participacijo (34-38 \%), in sicer je bil prvi najpomembnejši za univerzitetne učitelje, drugi pa za druge strokovnjake. Finance so oboji označili za najmanj po- 


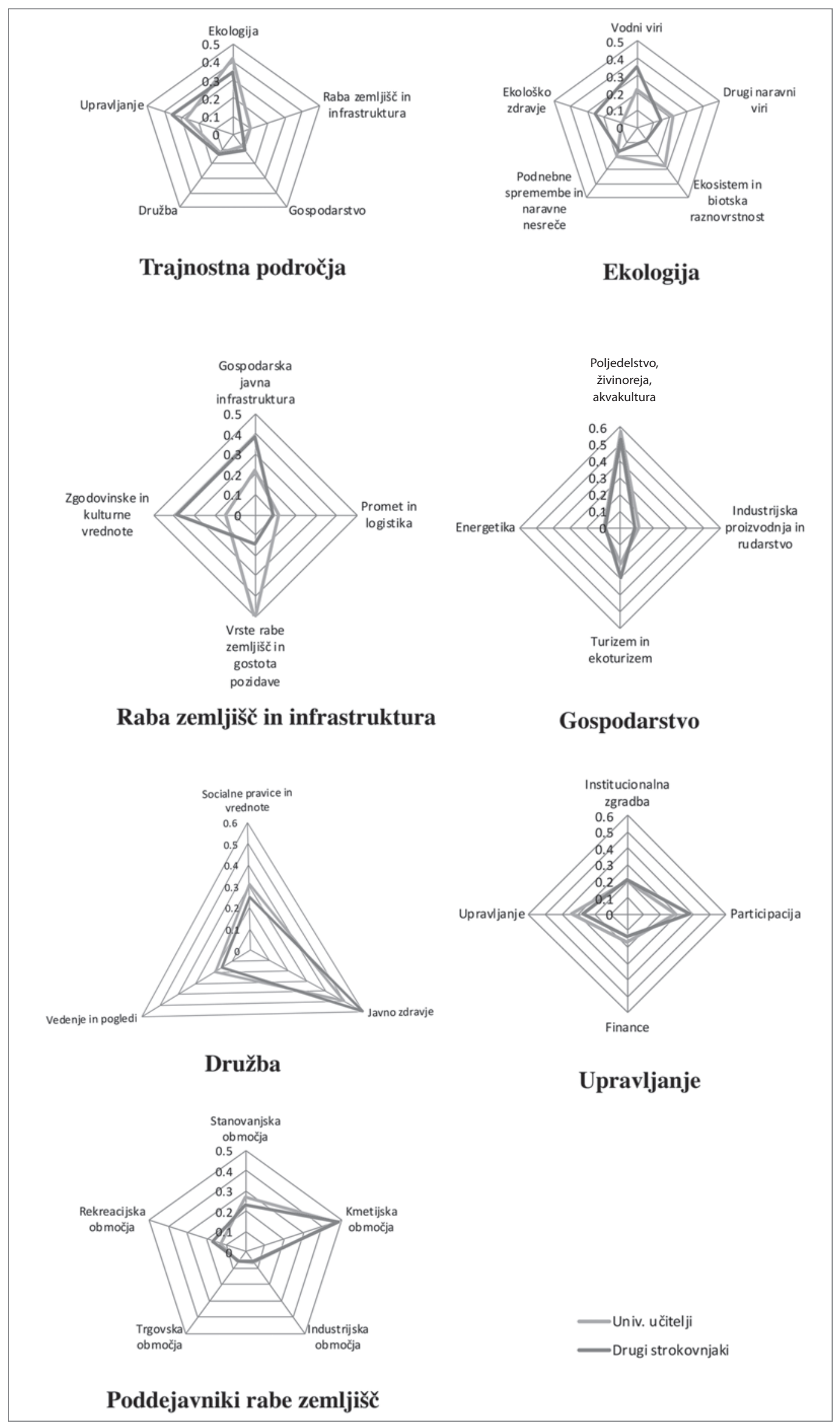

Slika 4: Primerjava odgovorov obeh skupin pri vrednotenju trajnostnih kriterijev načrtovanja in upravljanja povodij (ilustracija: avtorji) 
membne pri trajnostnem upravljanju in načrtovanju povodij. Pri vrednotenju poddejavnikov rabe zemljišč na tretji ravni hierarhije trajnosti, opredeljeni v tej raziskavi, so bila mnenja obeh skupin usklajena. Kot je prikazano na sliki 3, sta največji pomen pripisali kmetijskim območjem (47-48\%), nato stanovanjskim (23-27\%) in rekreacijskim območjem (13-17\%) ter nazadnje trgovskim $(6 \%)$ in industrijskim območjem (7 \%). Navedeno se zdi primerno, saj je kmetijstvo največji porabnik vode, stanovanjska območja pa so sestavni del povodij. Zaradi negativnih vplivov na vodne vire so trgovska in industrijska območja v načrtih povodij običajno zelo omejena, rekreacijske površine pa so na nekaterih območjih delno dovoljene glede na oddaljenost od vodnih teles.

Raziskava je dober primer uporabe AHP za vrednotenje trajnostnih kazalnikov. Metoda AHP je poleg tega uporabljena za ugotavljanje nasprotujočih si mnenj glede upravljanja in načrtovanja povodij, kar je edinstven način njene uporabe. Kot interdisciplinarni proces morata načrtovanje in upravljanje povodij vključevati in upoštevati različne vidike in sektorje, zato morajo odločevalci s področja upravljanja in varovanja povodij in pitne vode dobro poznati ključne dejavnike in vidike, ki jih je treba pri tem upoštevati. Izsledki raziskave so pokazali, da se mnenja strokovnjakov o posameznih področjih trajnosti močno razlikujejo, zlasti pri vrednotenju dejavnikov ekologije in rabe zemljišč. Drugi strokovnjaki so dejavnike, kot so ekosistemske funkcije, načrtovanje infrastrukture, vplivi rabe zemljišč, način upravljanja in drugi naravni viri, ovrednotili za manj pomembne pri trajnostnem upravljanju in načrtovanju povodij. Obe skupini anketirancev sta $\mathrm{v}$ glavnem podobno ovrednotili dejavnike gospodarstva, družbe, upravljanja voda in rabe zemljiišc (Slika 4). Drugi strokovnjaki, ki nimajo ustreznih informacij o ekosistemskih funkcijah, vplivih različne rabe zemljiššc, načinih upravljanja, družbenih in gospodarskih potrebah itd., ne morejo oblikovati načrta trajnostnega upravljanja povodij. Za opredelitev modela vrednotenja načrtov povodij z vidika trajnostnih načel, ki bi ga lahko uporabili za vse projekte načrtovanja in upravljanja povodij, je zato treba ugotoviti in uskladiti mnenja strokovnjakov z raznovrstnih področij.

\section{Sklep}

Upravljanje in načrtovanje vodnih virov sta povezana $s$ številnimi trajnostnimi dejavniki, vključno $\mathrm{z}$ ekologijo, gospodarstvom, družbo, rabo zemljišč in upravljanjem. Zaradi tega je tovrstno načrtovanje bolj zapleteno ter zahteva dinamičen, celosten in participativni pristop. Vključenost raznih skupin vodnih uporabnikov in deležnikov v odločanje je ključen dejavnik pri izbiri strategij upravljanja povodij in načrtovalskih pristopov. Sodelovanje med lokalnimi in vladnimi uradi ter javnimi ustanovami je treba zagotoviti že v prvi fazi načrtovalskega procesa. Vcasih pa se mnenja med drugimi strokovnjaki in univerzitetnimi učitelji, javnimi uporabniki in deležniki, regionalnimi načrtovalci in lokalnimi upravniki ter celo med strokovnjaki raznih strok (npr. med krajinskimi arhitekti, načrtovalci namenske rabe zemljišč, okoljevarstveniki, ekonomisti in upravniki povodij) lahko močno razlikujejo. Navedene razlike se lahko pojavijo v vseh fazah odločevalskega procesa in lahko zelo negativno vplivajo na odločitve pri oblikovanju načrtov za dodeljevanje vodnih virov, zemljišč in finančnih sredstev.

Raziskava, predstavljena v tem članku, je pokazala, da so si lahko mnenja nosilcev znanja in odločevalcev pri nekaterih vidikih vrednotenja dejavnikov trajnostnega razvoja vodnih virov zelo nasprotujoča, kar lahko preprečuje doseganje trajnostnih ciljev. Pred kakršnim koli resnim razmišljanjem o pripravi vodnogospodarskih načrtov povodij je treba določiti morebitne razlike v pogledih ciljnih skupin. $Z$ ugotavljanjem, na katerih področjih se mnenja razlikujejo, lahko bolje razumemo glavne izzive, ki se bodo pojavili v procesu odločanja ter pri določanju postopkov upravljanja in njihovi izvedbi. Tej težavi se lahko izognemo ali jo omilimo s sestanki, izobraževalnimi delavnicami in predstavitvenimi programi, ki omogočajo razpravo med raznimi skupinami odločevalcev, kot so raziskovalci, univerzitetni učitelji, nosilci znanja in vladni odločevalci. Navedeno se lahko zagotovi v vsaki fazi načrtovanja povodij, na primer pri določanju in razvrščanju ciljev, opredelitvi problemov, določanju upravljavskih strategij, predlaganju rešitev in dodeljevanju virov. Po koncu sestankov in razprav so lahko mnenja in pogledi udeležencev precej bolj usklajeni, na podlagi česar se lahko oblikujejo celovite rešitve.

\section{Sahar Pouya}

ITÜ Fen Bilimleri Enstitüsü, Şehir ve Bölge Planlaması Bölümü, Mimarlık Fakültesi, İstanbul Teknik Üniversitesi (Oddelek za urbani in regionalni razvoj, Podiplomska šola za znanstveni inženiring in tehnologijo, Tehnična univerza v Istanbulu), Istanbul, Turčija

E-naslov: pouya@itu.edu.tr

\section{Handan Turkoglu}

ITÜ Fen Bilimleri Enstitüsü, Şehir ve Bölge Planlaması Bölümü, Mimarlık Fakültesi, İstanbul Teknik Üniversitesi (Oddelek za urbani in regionalni razvoj, Fakulteta za arhitekturo, Tehnična univerza v Istanbulu), Istanbul, Turčija

E-naslov: turkoglu@itu.edu.tr

Umit Arpacioglu

Mimarlık Fakültesi, Mimar Sinan Güzel Sanatlar Üniversitesi Architecture (Univerza likovnih umetnosti Mimarja Sinana, Fakulteta za arhitekturo), Istanbul, Turčija

E-naslov: umitarpacioglu@gmail.com 


\section{Viri in literatura}

Arthington, A. H., Naiman, J. R., McClain, E. M., in Nilsson, C. (2009): Preserving the biodiversity and ecological services of rivers: New challenges and research opportunities. Freshwater Biology, 55(1), str. 1-16. DOI: $10.1111 /$ j.1365-2427.2009.02340

Barrow, C. J. (1998): River basin planning and development: A critical review. World Development, 26(1), str. 171-186. DOI: 10.1016/S0305-750X(97)10017-1

Basiago, D. (1999): Economic, social, and environmental sustainability in development theory and urban planning practice. The Environmentalist, 19, str. 145-161.

Belay, A., Semakula, M., Wambura, J. G., in Jan, L. (2010): SWOT analysis and challenges of Nile Basin Initiative: An integrated water resource management perspective. Chinese Journal of Population Resources and Environment, 8(1), str. 8-17. DOI: 10.1080/10042857.2010.10684960

Bhushan, N., in Rai, K. (2004): Strategic decision making: Applying the analytic hierarchy process. London, Springer.

Bilen, Ö. (2008): Turkey's water agenda: Water management and the EU water policy. DSI Official and Financial Affairs Administration, Ankara. Dostopno na: http://ozdenbilen.com/Dosyalar (sneto 30. 3. 2020).

Brooks, K. N., Folliott, P. F., in Magner, J. A. (2013): Hydrology and the management of watersheds. 4. izdaja. Ames, Wiley-Blackwell.

Chandniha, K. S., Kansal, M. L., in Anvesh, G. (2014): Watershed sustainability index assessment of a watershed in Chhattisgarh, India. Current World Environment, 9(2), str. 403-411. DOI: 10.12944/CWE.9.2.22

Chen, Y., Feng, Y., Zhang, F., in Wang, L. (2018): Assessing water resources vulnerability by using a rough set cloud model: A case study of the Huai River Basin, China. Entropy, 21(1), članek št. 14.

DOI: 10.3390/e21010014

Cox, W. E. (1987): The role of water in socio-economic development. Pariz, UNESCO.

Coyle, G. (2004): The analytic hierarchy process (AHP), practical strategy, open access material. London, Pearson Education.

Crase, L., in Cooper, B. (2015): Politics, socio-economics and water allocations: A note on the limits of integrated water resources management. Australasian Journal of Environmental Management, 22(4), str. 388-399. DOI: 10.1080/14486563.2015.1041068

Curiel-Esparza, J., Cuenca-Ruiz, A. M., Martin-Utrillas, M., in Canto-Perello, J. (2014): Selecting a sustainable disinfection technique for wastewater reuse projects. Water, 6(9), str. 2732-2747. DOI: 10.3390/w6092732

Dinar, A., Kemper, K., Blomquist, W., in Kurukulasuriya, P. (2007): Whitewater: Decentralization of river basin water resource management. Journal of Policy Modeling, 29, str. 851-867.

DOI: 10.1016/j.jpolmod.2007.06.013

Füssel, H. M. (2007): Vulnerability: A generally applicable conceptual framework for climate change research. Global Environmental Change, 17(2), str. 155-167. DOI: 10.1016/j.gloenvcha.2006.05.002

Global Water Partnership (2000): Integrated water resources management. TAC Background Papers. Št. 4. Stockholm.

Ide, K. S., Niandou, S. A., Naimi, M., Chikhaoui M., in Schimmel, K. (2019): Analysis of water resources vulnerability assessment tools. Journal of Agricultural Science and Technology, B 9, str. 69-86. DOI: 10.17265/2161-6264/2019.02.001

Internet 1: https://sustainabledevelopment.un.org/content/documents/ Agenda21.pdf (sneto 30. 3. 2020).
Jønch-Clausen, T., in Fugl, J. (2001): Firming up the conceptual basis of integrated water resources management. Water Resources Development, 17(4), str. 501-510. DOI: 10.1080/07900620120094055

Keating, M. (1993): The Earth Summit's agenda for change: A plain language version of Agenda 21 and the other Rio Agreements. Ženeva, Centre for Our Common Future. DOI: 10.1016/0959-3780(94)90026-4

Kennedy, C., Baker, L., Dhakal, S., in Ramaswami, A. (2012): Sustainable urban systems: An integrated approach. Journal of Industrial Ecology, 16(6). DOI: 10.1111/j.1530-9290.2012.00564.x

Kharrazi, A. (2016): Evaluating the evolution of the Heihe River basin using the ecological network analysis: Efficiency, resilience, and implications. Science of the Total Environment, 572, str. 688-696. DOI: 10.1016/j.scitotenv.2016.06.210

Kirby, C., in White, W. R. (ur.) (1994): Integrated river basin development. Chichester, Wiley.

Lal, P., Lim-Applegate, H., in Scoccimarro, M. (2001): The adaptive decision-making process as a tool for integrated natural resource management: Focus, attitudes, and approach, Conservation Ecology, 5(2), članek 11. DOI: 10.5751/es-00306-050211

Loucks, D. P., in Gladwell, J. (1999): Sustainability criteria for water resource systems. Cambridge, Cambridge University Press.

Loucks, D. P., in Beek, van E. (2017): Water resources systems planning and management. An introduction to methods, models and applications. Cham, Springer. DOI: 10.1007/978-3-319-44234-1_1

Mays, L. (2006) Water resources sustainability. New York, McGraw-Hill Professional.

Mencio, A., Folch, A., in Mas-Pla, J. (2010): Analyzing hydrological sustainability through water balance. Environmental Management, 45(5), str. 1175-1190. DOI: 10.1007/s00267-010-9461-y

Michael, L. F., Noor, Z. Z., Zardari, H. N., in Meza, F. J. M. (2013): Analytical hierarchy process application in urban sustainability indicators prioritization. Resources and Environment, 3(5A), str. 1-5.

DOI: 10.5923/s.re.201309.01

Molle, F. (2006) Planning and managing water resources at the river-basin level: Emergence and evolution of a concept. Comprehensive assessment research report 16. Colombo, Šrilanka, International Water Management Institute. Dostopno na: https://www.iwmi.cgiar.org/assessment/files_new/publications/CA\%20Research\%20Reports/CARR16. pdf (sneto 7. 2. 2020).

New York State Department of State (2009): Guidebook: Watershed plans: Protecting and restoring water quality. Dostopno na: https://www.dos.ny.gov/opd/sser/pdf/WatershedPlansGuidebook. pdf (sneto 7. 3. 2020).

Oddershede, A., Arias, A., in Cancino, H. (2007): Rural development decision support using the analytic hierarchy process. Mathematical and Computer Modelling, 46(7-8), str. 1107-1114.

DOI: 10.1016/j.mcm.2007.03.006

Ouyang, Y. (2012): A potential approach for low flow selection in water resource supply and management. Dostopno na: http://dx.doi. org/10.1016/j.jhydrol.2012.05.062 (sneto 7. 3. 2020).

Räsänen, A., Juhola, S., Monge, M. A., Käkönen, M., Kanninen, M., in Nygren, A. (2017): Identifying mismatches between institutional perceptions of water-related risk drivers and water management strategies in three river basin areas. Journal of Hydrology, 550, str. 704-715. DOI: 10.1016/j.jhydrol.2017.05.040 
Ruiz-Villaverde, A., González-Gómez, F., in Picazo-Tadeo, J. A. (2013): Public choice of urban water service management: A multi-criteria approach. International Journal of Water Resources Development, 29(3), str. 385-399. DOI: 10.1080/07900627.2012.721668

Saaty, T. L. (1994): How to make a decision: The analytic hierarchy process. Interfaces, 24(6), str. 19-43. DOI: 10.1287/inte.24.6.19

Shafabakhsh, G., Mirzanamadi, R., in Mohammadi, M. (2015): Pedestrians' mental satisfaction's relationship with physical characteristics on sidewalks using analytical hierarchy process: Case study of Tehran, Iran. Transportation Letters, 7(3), str. 121-132. DOI: 10.1179/1942787514Y.0000000039

Shen, L. Y., Ochoa, J. J., Shah, N. M., in Zhang, X. (2011): The application of urban sustainability indicators: A comparison between various practices. Habitat International, 35(1), str. 17-29.

DOI: 10.1016/j.habitatint.2010.03.006

Srinivas, R., Singh, P. A., Dhadse, K., Garg, C., in Deshmukh, A. (2018): Sustainable management of a river basin by integrating an improved fuzzy based hybridized SWOT model and geo-statistical weighted thematic overlay analysis. Journal of Hydrology, 563 (2018), str. 92-105. DOI: 10.1016/j.jhydrol.2018.05.059

Tezer, A., Uzun, O., Okay, N., in Karacor, E. (2018): The importance of identification of Ecosystem-based services on the watershed conservation areas of Melen basin/Duzce. Journal of Kentli: Drinking water basins (Turkish Healthy Cities Association), 30(9), str. 58-60.

Thapa, B. R., in Murayama, Y. (2010): Drivers of urban growth in the Kathmandu valley, Nepal: Examining the efficacy of the analytic hierarchy process. Applied Geography, 30, str. 70-83.

DOI: 10.1016/j.apgeog.2009.10.002

Thomas, J., in Durham, B. (2003): Integrated water resource management: Looking at the whole picture. Desalination, 156(1-3), str. 21-28. DOI: 10.1016/S0011-9164(03)00320-5

Thungngern, J., Sriburi, T., in Wijitkosum, S. (2017): Analytic hierarchy process for stakeholder participation in integrated water resources management. Engineering Journal, 21(7). DOI: 10.4186/ej.2017.21.7.87

Türkiye Cumhuriyeti Kalkınma Bakanlığı (2014) National strategy of regional development 2014-2023. Available at: https://www.turkiye.gov. tr/kalkinma-bakanligi (sneto 7. 3. 2020).

Wani, P., Sreedevi, T. K., Reddy, T. S. V., Venkateswarlu, B., in Prasad, C. S. (2008): Community watersheds for improved livelihoods through consortium approach in drought prone rain-fed areas. Journal of Hydrological Research and Development, 23, str. 55-77.

WCED (1987): Our common future. London.

Yang, W., Hyndman, D. W., Winkler, J. A., Vina, A., Deines, J., Lupi, F., idr. (2016): Urban water sustainability: Framework and application. Ecology and Society, 21(4), str. 4. DOI: 10.5751/ES-08685-210404

Yavuz, F., in Baycan, T. (2013): Use of SWOT and analytic hierarchy process integration as a participatory decision making tool in watershed management. Procedia Technology, 8, str. 134-143.

DOI: 10.1016/j.protcy.2013.11.019

Združeni narodi (2014): World urbanization prospects: The 2014 revision. New York.

Zhou, X., Li, Y., in Lai, F. (2018): Effects of different water management on absorption and accumulation of selenium in rice. Saudi J Biol Sci, 25(6), str. 1178-1182. DOI: 10.1016/j.sjbs.2017.10.017 